\title{
Erratum to: Treatment with D-penicillamine or zinc sulphate affects copper metabolism and improves but not normalizes antioxidant capacity parameters in Wilson disease
}

\author{
Grażyna Gromadzka • Agata Karpińska - Adam Przybyłkowski • \\ Tomasz Litwin • Agata Wierzchowska-Ciok - Karolina Dzieżyc • \\ Grzegorz Chabik • Anna Członkowska
}

Published online: 21 January 2014

(C) Springer Science+Business Media New York 2014

\section{Erratum to: Biometals}

DOI 10.1007/s10534-013-9694-3

Due to an unfortunate turn of events, the first- and surnames of all authors were transposed in the original publication. The correct representation of the authors and their affiliations are listed above and below and should be treated as definitive by the reader.

The online version of the original article can be found under doi:10.1007/s10534-013-9694-3.

G. Gromadzka $(\bowtie) \cdot$ T. Litwin · A. Wierzchowska-Ciok · K. Dzieżyc · G. Chabik · A. Członkowska Second Department of Neurology, Institute of Psychiatry and Neurology, Sobieskiego 9, 02-957 Warsaw, Poland e-mail: gromadz@ipin.edu.pl

A. Karpińska · A. Przybyłkowski · A. Członkowska Department of Experimental and Clinical Pharmacology, Medical University of Warsaw, Warsaw, Poland 